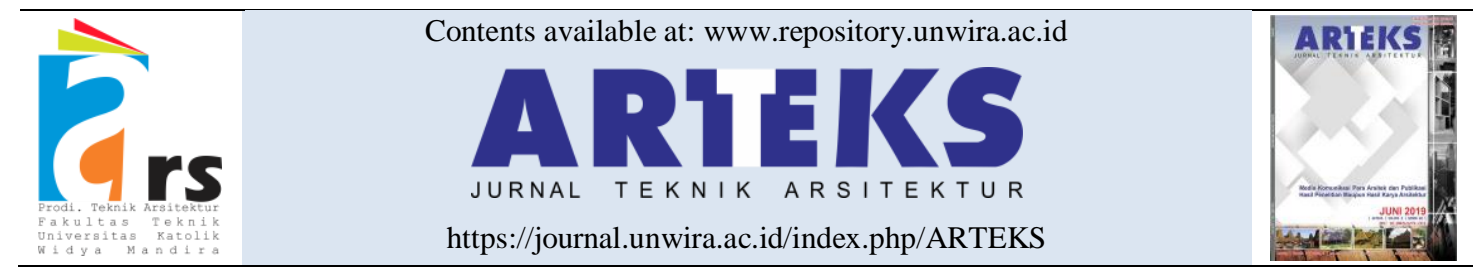

Research paper

doi: http://doi.org/10.30822/arteks.v5i2.402

\title{
Tipologi pengembangan kawasan berbasis transit di kawasan Stasiun Maguwo, Yogyakarta
}

\author{
Agus Setiawan ${ }^{(1)}$, Ikaputra*(i) \\ Departemen Teknik Arsitektur, Fakultas Teknik, Universitas Gadjah Mada \\ Jl. Grafika no. 2 Bulaksumur, Yogyakarta-55281, Indonesia
}

\begin{tabular}{l}
\hline ARTICLE INFO \\
\hline Article history: \\
Received February 28, 2020 \\
Received in revised form March 02, \\
2020 \\
Accepted April 18, 2020 \\
Available online August 01, 2020
\end{tabular}

ABSTRACT
Transit oriented development (TOD) typology in Maguwo train
station area, Yogyakarta

Transit oriented development (TOD) is a concept to address problems related to the lack of public transportation use in urban areas. Empirical conditions in Maguwo station area have not applied the TOD principle, especially related to density and

Keywords:

Area development

Concept of transit orientation

Maguwo train station diversity aspects, which results in the low intensity of public transportation use, based on these conditions it is necessary to reposition the area with TOD concept. Repositioning Maguwo station area with TOD concept begins with a review of existing conditions and TOD typologies that ideal to be implied in Maguwo station area, finding gaps between existing conditions and ideal TOD typology, and recommendations for resolving the gaps, will be input for design process of TOD area. The study uses quantitative

*Corresponding author: Ikaputra Departemen Teknik Arsitektur, Fakultas Teknik, Universitas Gadjah Mada, Indonesia Email: ikaputra@ugm.ac.id ORCID: https://orcid.org/0000-0003-04516699 and qualitative deductive methods with research variables including character of regional development, variety, and intensity of spatial use. The research showed the ideal TOD typology applied in Maguwo station area was a sub urban TOD. The gap between the existing conditions and sub urban TOD standard is the lack of residential units and the low intensity of spatial use including building, residential, and population density. Therefore, the design area need to add the number of residential units and increase the intensity of building density to match the sub urban TOD standard.

\section{Pendahuluan}

Kota ditempati oleh pelbagai individu yang heterogen dan menempati area yang cukup luas dan padat (Kostof 1991). Heterogenitas fungsi dalam kota mendorong terjadinya pergerakan untuk memenuhi kebutuhan masyarakat antara satu area dengan area yang lain, dengan sarana transportasi menjadi moda untuk memfasilitasnya (Gultom 2015). Pertumbuhan jumlah kendaraan bermotor dan masih rendahnya penggunaan moda transportasi publik menimbulkan permasalahan di perkotaan, diantaranya kemacetan lalu lintas, polusi udara, dan dampak sosial ekonomi pengguna jalan (Motieyan and Mesgari 2017; C. Wijaya 2018; Wijaya and Sari 2020)

Pengembangan kawasan berbasis transit atau transit-oriented development (TOD) merupakan konsep untuk menjawab permasalahan kawasan khususnya terkait dengan minimnya penggunaan transportasi publik (Calthorpe and Mintier 2011). Transit-oriented development (TOD) akan mengurangi penggunaan moda transportasi pribadi dan mendorong penggunaan moda transportasi umum, memfasilitasi para pejalan kaki, dan penggunaan moda transportasi nonmesin di sekitar simpul yang dirancang dengan guna lahan campur di sekitar stasiun 
(Renne 2005). Transit-oriented development (TOD) adalah upaya untuk menjadikan berjalan kaki dan penggunaan moda transportasi umum sebagai gaya hidup (Gomez, Omar, and Nallusamy 2019).

Transit-oriented development (TOD) adalah integrasi antara guna lahan dan transportasi publik untuk menciptakan pengembangan mixed-use yang relatif padat di sekitar titik transit (Holling and McKenzie 2009). TOD menjadikan komunitas di sekitar titik transit sebagai pusat kegiatan, guna lahan direncanakan dengan kompak dengan variasi fungsi, menarik untuk berjalan kaki (Community Design + Architecture 2001).

Kawasan transit-oriented development (TOD) dapat dibedakan menjadi 3 tipologi yaitu transitoriented development (TOD) kota, transitoriented development (TOD) sub kota, dan transit-oriented development (TOD) lingkungan. Masing-masing tipologi mempunyai skala pelayanan, karakter pengembangan, dan tingkat kepadatan yang berbeda-beda (Indonesia 2017; Tong et al. 2018)

Transit-oriented development (TOD) Kota direncanakan untuk layanan skala regional dengan dominasi fungsi nonperumahan dan kepadatan tinggi. Transit-oriented development (TOD) sub kota direncanakan untuk pusat perekonomian dengan fungsi sekunder, persentase fungsi perumahan 30\%-60\% dan non perumahan $40 \%-70 \%$, dengan karakter kepadatan tinggi -sedang. Sedangkan transit-oriented development (TOD) lingkungan adalah sebagai layanan perekonomian lokal, dengan dominasi fungsi perumahan, dengan kepadatan sedang (Indonesia 2017).

Setiap tipologi transit-oriented development (TOD) dikembangkan dengan standar teknis yang berbeda-beda terkait dengan karakter pengembangan yang spesifik antara satu tipologi dengan tipologi yang lain, standar teknis tersebut meliputi tipe moda tranportasi dan sistem transit yang direncanakan, ragam pemanfaatan ruang, intensitas dan kepadatan pemanfatan ruang (kepadatan bangunan, hunian, populasi, dan pekerjaan) serta aspek yang terkait dengan faktor kemudahan bagi pejalan kaki (Indonesia 2017).

Secara lokasi, posisi stasiun Maguwo sangat strategis dalam konteks jarak dan konektifitas antara 3 stasiun besar yaitu stasiun Solo Balapan, stasiun Tugu, dan stasiun Wojo yang merupakan titik transit menuju Yogyakarta International
Airport (YIA), dan juga status stasiun Maguwo sebagai stasiun bandara Adisutjipto Yogyakarta.

Kondisi empiris kawasan stasiun Maguwo dan bandara Adisutjipto sudah diupayakan sistem integrasi intermoda yang baik antara 4 moda transportasi yaitu pesawat udara (melalui bandara Adisutjipto), kereta api (melalui stasiun Maguwo), bus Trans Jogja (melalui halte bandara), dan bus antar kota (bus Damri) yang melayani rute menengah dan jarak jauh.

Permasalahan yang menjadi dasar penelitian dirumuskan dari kesenjangan antara kondisi ideal dengan kondisi empiris yang saat ini terjadi dikawasan stasiun Maguwo. Kondisi empiris stasiun Maguwo jika dilihat dari aspek keterpaduan intermoda sudah cukup baik, hal ini terlihat dengan adanya konektivitas yang sudah terdefinisi dengan baik antara stasiun menuju halte bus Trans Jogja, stasiun menuju terminal bandara, stasiun menuju shelter bus Damri dan sebaliknya. Tetapi, jika dilihat dari prinsip-prinsip transit-oriented development (TOD) yaitu densitas, diversitas, design for walkability, design to transit, destination accessibility (Widyastuti 2017), khususnya yang terkait dengan aspek densitas dan diversitas, maka kondisi empiris tata guna lahan dikawasan stasiun Maguwo belum dimanfaatkan dengan baik, hal ini terlihat dari dominasi tata guna lahan yang hanya dimanfaatakan sebagai area parkir bandara dan fungsi komersial 1 lantai pada radius $400 \mathrm{~m}$ dari stasiun Maguwo, sehingga berdasar kondisi di atas perlu dilakukan penataan kembali kawasan stasiun Maguwo dengan menerapkan prinsip transit-oriented development (TOD).

Penataan kawasan stasiun Maguwo dengan konsep transit-oriented development (TOD) diawali dengan tinjauan eksisting kawasan stasiun Maguwo, dan tinjauan tipologi transit-oriented development (TOD) yang ideal untuk dikembangkan di kawasan stasiun Maguwo.

Tujuan penelitian ini adalah menemukan tipologi transit-oriented development (TOD) yang ideal untuk dikembangkan dikawasan stasiun Maguwo dan menemukan faktor apa saja yang saat ini belum terpenuhi atau kesenjangan untuk mencapai kondisi ideal tersebut. Sehingga manfaat kedepan dari penelitian ini dapat digunakan sebagai acuan penerapan prinsip transit-oriented development (TOD) didalam desain, dalam rangka menyelesaikan kesenjangan antara kondisi eksisting dengan tipologi transitoriented development (TOD) ideal yang akan dikembangkan. 


\section{Metode penelitian}

Pendekatan penelitian yang dilakukan adalah dengan metode deduktif kuantitatif dan kualitatif. Fokus penelitian meliputi dua hal yaitu:

1. Bagaimana kondisi eksisting kawasan stasiun Maguwo dilihat dari aspek dominasi fungsi, ragam, dan intensitas pemanfaatan ruang?

2. Apakah tipologi transit-oriented development (TOD) yang ideal dikembangkan di kawasan stasiun Maguwo, apakah transit-oriented development (TOD) kota, transit-oriented development (TOD) sub kota, atau TOD lingkungan? dan apa rekomendasi untuk mencapai tipologi transit-oriented development (TOD) tersebut?

Fokus penelitian nomor 1 menjadi penting dalam rangka melihat kesenjangan antara kondisi eksisting dengan tipologi transit-oriented development (TOD) ideal yang akan dicapai pada fokus penelitian nomor 2 .

Data primer berupa tata fungsi, guna lahan, jumlah lantai bangunan, tata sirkulasi, dan sebaran titik transit dikawasan eksisting stasiun Maguwo didapatkan dengan observasi lapangan. Peta dasar untuk acuan survey dibuat berdasarkan hasil tracing citra satelit.

Data sekunder didapatkan dari studi pustaka, dokumen rencana tata ruang wilayah, dokumen rencana pengembangan kawasan, dan data digital yang terkait.

Data yang diperoleh kemudian dikompilasi dan dianalisa berdasarkan variabel, parameter, dan indikator yang digunakan untuk menjawab fokus penelitian. Variabel, parameter, dan indikator yang digunakan ditunjukan dalam tabel 1 berikut:

Tabel 1. Kepadatan unit hunian

\begin{tabular}{|c|c|c|c|}
\hline Tipologi & Variabel & Parameter & Indikator \\
\hline \multirow[t]{6}{*}{$\begin{array}{l}\text { TOD } \\
\text { kota }\end{array}$} & 1. Moda transportasi & $\begin{array}{l}\text { Jenis moda tranportasi } \\
\text { Headway }\end{array}$ & $\begin{array}{l}\text { Heavy rail, light rail, BRT, bus lokal, bus ekspres } \\
<5 \text { Menit }\end{array}$ \\
\hline & $\begin{array}{l}\text { 2. Karakter } \\
\text { pengembangan }\end{array}$ & $\begin{array}{l}\text { Lingkup layanan } \\
\text { Dominasi fungsi }\end{array}$ & $\begin{array}{l}\text { Pusat perekonomian skala regional } \\
\text { Dominasi fungsi non perumahan }\end{array}$ \\
\hline & $\begin{array}{l}\text { 3.Ragam } \\
\text { Pemanfaatan } \\
\text { ruang }\end{array}$ & $\begin{array}{l}\text { Perumahan } \\
\text { Non perumahan }\end{array}$ & $\begin{array}{l}20 \%-60 \% \\
40 \%-80 \%\end{array}$ \\
\hline & $\begin{array}{l}\text { 4. Intensitas } \\
\text { pemanfaatan } \\
\text { ruang }\end{array}$ & $\begin{array}{l}\text { Kepadatan bangunan } \\
\text { Kepadatan populasi } \\
\text { Kepadatan hunian } \\
\text { Kepadatan pekerja }\end{array}$ & $\begin{array}{l}\text { KDB } 80 \%, \text { KLB }>5.0, \text { kepadatan tinggi } \\
>750 \mathrm{jiwa} / \mathrm{ha} \\
>38 \mathrm{unit} / \mathrm{ha} \\
>200 \mathrm{jiwa} / \mathrm{ha}\end{array}$ \\
\hline & 5. Walkability & Dimensi blok & $70-130$ meter \\
\hline & 6. Parkir & Park and ride & Tidak \\
\hline \multirow[t]{6}{*}{$\begin{array}{l}\text { TOD } \\
\text { sub kota }\end{array}$} & 1. Moda transportasi & $\begin{array}{l}\text { Jenis moda tranportasi } \\
\text { Headway }\end{array}$ & $\begin{array}{l}\text { Heavy rail, light rail, BRT, bus lokal, bus ekspres } \\
5-15 \text { menit }\end{array}$ \\
\hline & $\begin{array}{l}\text { 2. Karakter } \\
\text { pengembangan }\end{array}$ & $\begin{array}{l}\text { Lingkup layanan } \\
\text { Dominasi fungsi }\end{array}$ & $\begin{array}{l}\text { Pusat perekonomian sekunder } \\
\text { Dominasi fungsi nonperumahan }\end{array}$ \\
\hline & $\begin{array}{l}\text { 3.Ragam } \\
\text { Pemanfaatan } \\
\text { ruang }\end{array}$ & $\begin{array}{l}\text { Perumahan } \\
\text { Non perumahan }\end{array}$ & $\begin{array}{l}30 \%-60 \% \\
40 \%-70 \%\end{array}$ \\
\hline & $\begin{array}{l}\text { 4. Intensitas } \\
\text { pemanfaatan } \\
\text { ruang }\end{array}$ & $\begin{array}{l}\text { Kepadatan bangunan } \\
\text { Kepadatan populasi } \\
\text { Kepadatan pekerja }\end{array}$ & $\begin{array}{l}\text { KDB } 70 \% \text {, KLB 3-5, kepadatan sedang-tinggi } \\
450-1500 \mathrm{jiwa} / \mathrm{ha} \\
40-200 \mathrm{jiwa} / \mathrm{ha}\end{array}$ \\
\hline & 5. Walkability & Dimensi blok & $70-200 \mathrm{~m}$ \\
\hline & 6. Parkir & Park and ride & Tidak \\
\hline \multirow[t]{6}{*}{$\begin{array}{l}\text { TOD } \\
\text { lingkungan }\end{array}$} & 1. Moda transportasi & $\begin{array}{l}\text { Jenis moda tranportasi } \\
\text { Headway }\end{array}$ & $\begin{array}{l}\text { Light rail, BRT, bus lokal, bus feeder } \\
15-30 \text { menit }\end{array}$ \\
\hline & $\begin{array}{l}\text { 2. Karakter } \\
\text { pengembangan }\end{array}$ & $\begin{array}{l}\text { Lingkup layanan } \\
\text { Dominasi fungsi }\end{array}$ & $\begin{array}{l}\text { Pusat aktivitas ekonomi lokal } \\
\text { Dominasi fungsi hunian }\end{array}$ \\
\hline & $\begin{array}{l}\text { 3. Ragam } \\
\text { pemanfaatan } \\
\text { ruang }\end{array}$ & $\begin{array}{l}\text { Perumahan } \\
\text { Nonperumahan }\end{array}$ & $\begin{array}{l}60 \%-80 \% \\
20 \%-40 \%\end{array}$ \\
\hline & $\begin{array}{l}\text { 4. Intensitas } \\
\text { pemanfaatan } \\
\text { ruang }\end{array}$ & $\begin{array}{l}\text { Kepadatan bangunan } \\
\text { Kepadatan populasi } \\
\text { Kepadatan hunian } \\
\text { Kepadatan pekerja } \\
\end{array}$ & $\begin{array}{l}\text { KDB } 70 \% \text {, KLB 2-3, kepadatan sedang } \\
350-1000 \mathrm{jiwa} / \mathrm{ha} \\
>25 \mathrm{unit} / \mathrm{ha} \\
12-40 \mathrm{jiwa} / \mathrm{ha}\end{array}$ \\
\hline & 5. Walkability & 1. Dimensi blok & $70-270 \mathrm{~m}$ \\
\hline & 6. Parkir & 1. Park and ride & Ya \\
\hline
\end{tabular}




\section{Temuan dan pembahasan}

Pada penelitian ini digunakan 3 dari 6 variabel penelitian yang digunakan untuk menilai kondisi eksisting dan mengklasifikasikan tipologi transitoriented development (TOD) yang ideal untuk dikembangkan, tiga variabel tersebut meliputi:(a) karakter pengembangan, (b) ragam pemanfaatan ruang, dan (c) intensitas pemanfaatan ruang. Deliniasi lokus penelitian adalah pada walkable distance atau radius $400 \mathrm{~m}$ (Indonesia 2017) dari stasiun Maguwo, dan juga area diantara radius 400-800 m dengan luas area +/- 63,5 Ha. Deliniasi lokus penelitian dibatasi dengan garis merah dalam gambar 1 di bawah ini:

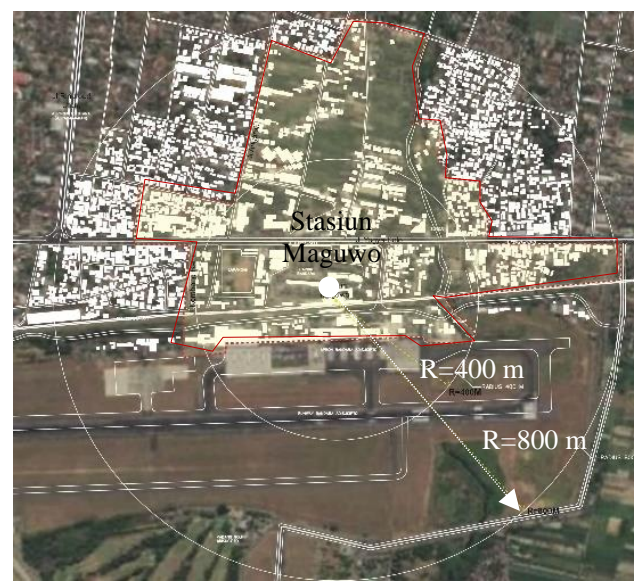

$=$ Deliniasi lokus penelitian

Gambar 1. Deliniasi lokus penelitian

\section{Kondisi eksisting}

Karakter pengembangan

Parameter yang digunakan untuk menilai karakter pengembangan adalah dengan melihat dominasi fungsi bangunan yang ada di dalam kawasan tersebut. Dominasi fungsi dihitung berdasarkan peta tata fungsi dan peta jumlah lantai bangunan didalam area penelitian. Dengan melihat peta fungsi dan jumlah lantai maka dapat dihitung luas total lantai fungsi bangunan yang mendominasi di area penelitian. Tata fungsi bangunan pada lokus penelitian ditunjukan dalam gambar 2 berikut:

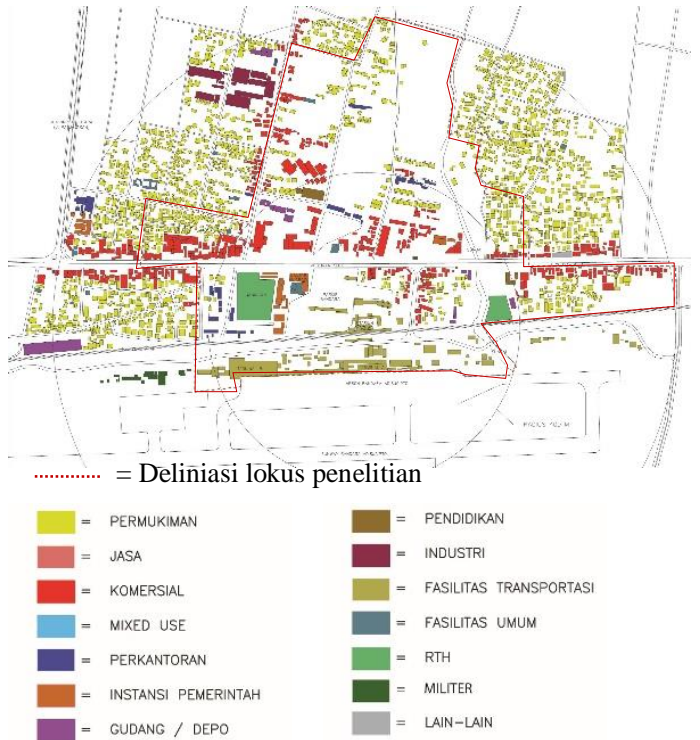

Gambar 2. Tata fungsi bangunan eksisting

Sedangkan peta jumlah lantai bangunan ditunjukan dalam gambar 3 berikut:

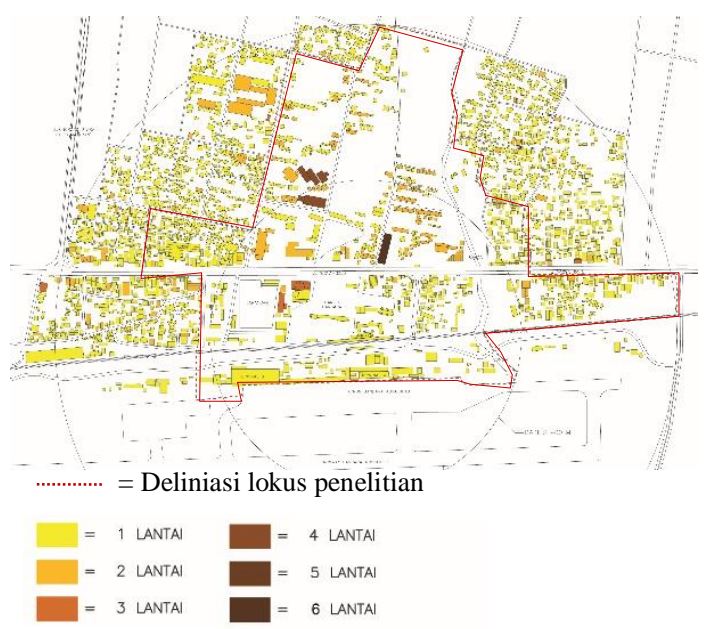

Gambar 3. Jumlah lantai bangunan eksisteing

Hasil perhitungan menunjukan tiga dominasi fungsi di lokus penelitian yaitu fungsi komersial $41,4 \%$, permukiman $25,4 \%$, dan transportasi $15,4 \%$ dari total luas lantai bangunan yang ada di lokus penelitian. Hasil perhitungan dominasi fungsi ditunjukan dalam diagram 1 berikut: 


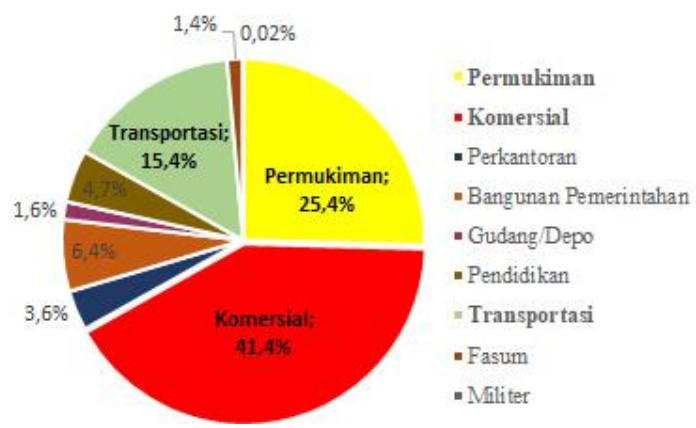

Diagram 1. Dominasi fungsi bangunan eksisting

Ragam pemanfaatan ruang

Ragam pemanfaatan ruang dibedakan untuk fungsi perumahan dan fungsi nonperumahan, perhitungan didasarkan pada persentase fungsi bangunan seperti dalam diagram 2 di bawah ini:

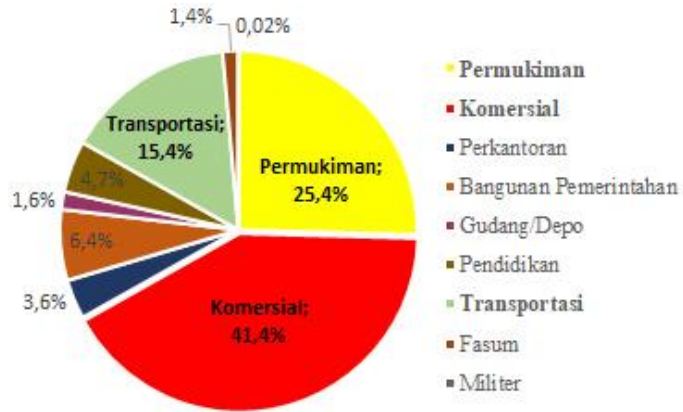

Diagram 2. Persentase fungsi bangunan eksisting

Dari persentase pada diagram 2 diatas, dapat dihitung perbandingan antara fungsi perumahan dan non-perumahan seperti ditunjukan dalam diagram 3 berikut:

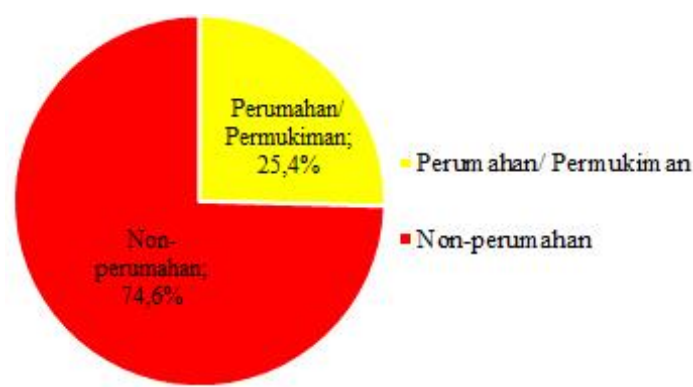

Diagram 3. Perbandungan fungsi perumahannonperumahan

Hasil perhitungan menunjukan persentase fungsi perumahan $25,4 \%$ dan fungsi nonperumahan $74,6 \%$ dari total luas fungsi bangunan.
Intensitas pemanfaatan ruang

Dalam menilai intensitas pemanfaatan ruang digunakan 4 parameter yaitu: (a) kepadatan bangunan meliputi data koefisien dasar bangunan (KDB) dan koefisien lantai bangunan (KLB), (b) kepadatan unit hunian, (c) kepadatan populasi, dan (d) kepadatan pekerjaan.

Untuk memudahkan perhitungan intensitas pemanfaatan ruang, lokus penelitian dibagi menjadi 7 blok seperti tergambar dalam gambar 4 berikut ini:

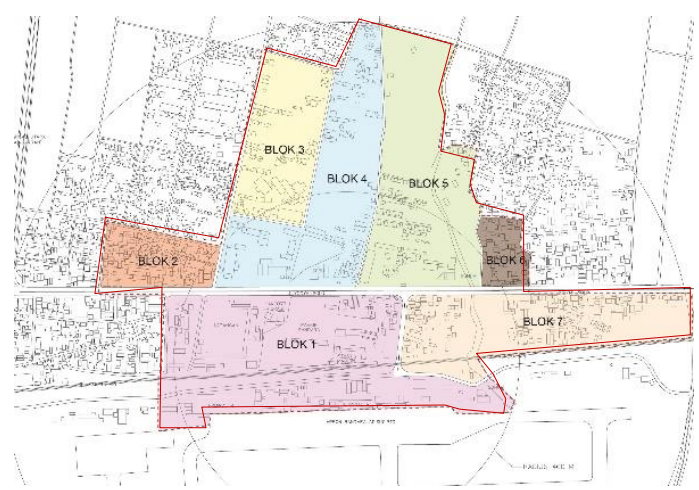

Gambar 4. Pembagian blok penelitian

Kepadatan bangunan terdiri dari KDB dan KLB, hasil perhitungan ditunjukan dalam tabel 2 berikut:

Tabel 2. KDB dan KLB rata-rata bangunan

\begin{tabular}{cccccc}
\hline Blok & $\begin{array}{l}\text { Luas } \\
\text { lahan } \\
\left(\mathbf{m}^{2}\right)\end{array}$ & $\begin{array}{l}\text { Total } \\
\text { luas It. } \\
\text { dasar } \\
\left(\mathbf{m}^{2}\right)\end{array}$ & $\begin{array}{l}\text { Total } \\
\text { luas } \\
\text { lantai } \\
\left(\mathbf{m}^{2}\right)\end{array}$ & KDB & KLB \\
\hline 1 & 165.608 & 33.658 & 37.757 & $20,3 \%$ & 0,23 \\
\hline 2 & 39.786 & 14.117 & 14.317 & $35,5 \%$ & 0,36 \\
\hline 3 & 69.392 & 12.387 & 27.052 & $17,9 \%$ & 0,39 \\
\hline 4 & 117.189 & 16.825 & 20.497 & $14,4 \%$ & 0,17 \\
\hline 5 & 128.959 & 10.231 & 24.676 & $7,9 \%$ & 0,19 \\
\hline 6 & 18.687 & 5.321 & 5.383 & $28,5 \%$ & 0,29 \\
\hline 7 & 96.126 & 18.533 & 20.007 & $19,3 \%$ & 0,21 \\
\hline Total & $\mathbf{6 3 5 . 7 4 7}$ & $\mathbf{1 1 1 . 0 7 2}$ & $\mathbf{1 4 9 . 6 8 9}$ & & \\
\hline KDB dan KLB rata-rata & & $\mathbf{1 7 , 5 \%}$ & $\mathbf{0 , 2 4}$ \\
\hline
\end{tabular}

Kepadatan unit hunian dihitung dengan cara jumlah unit hunian dibagi luas lahan dalam satuan hektar (ha) (Brisbane 2011), hasil perhitungan ditunjukan dalam tabel 3 berikut: 
Tabel 3. Kepadatan unit hunian

\begin{tabular}{lll}
\hline Area & $\begin{array}{l}\text { Luas Lahan } \\
\text { (ha) }\end{array}$ & $\begin{array}{l}\text { Jumlah hunian } \\
\text { (unit) }\end{array}$ \\
\hline Blok 1 & 16,56 & 27 \\
\hline Blok 2 & 3,98 & 107 \\
\hline Blok 3 & 6,94 & 33 \\
\hline Blok 4 & 11,72 & 61 \\
\hline Blok 5 & 12,90 & 39 \\
\hline Blok 6 & 1,87 & 59 \\
\hline Blok 7 & 9,61 & 114 \\
\hline Total & $\mathbf{6 3 , 5 7}$ & $\mathbf{4 4 0}$ \\
\hline Jumlah hunian/ha & $=$ & $\mathbf{7}$ unit/ha \\
\hline
\end{tabular}

Kepadatan populasi adalah jumlah populasi penduduk yang tinggal dilokus penelitian dibagi total luas lahan (ha), jumlah populasi dihitung dari jumlah unit hunian yang ada (Landcom 2011), dengan asumsi 4 jiwa menempati setiap 1-unit hunian, hasil perhitungan kepadatan populasi ditunjukan dalam tabel 4 berikut:

Tabel 4. Kepadatan populasi

\begin{tabular}{llll}
\hline Blok & $\begin{array}{l}\text { Luas } \\
\text { lahan } \\
\text { (ha) }\end{array}$ & $\begin{array}{l}\text { Jumlah } \\
\text { hunian } \\
\text { (unit) }\end{array}$ & $\begin{array}{l}\text { Jumlah populasi } \\
\text { (asumsi 4 } \\
\text { jiwa/unit) }\end{array}$ \\
\hline 1 & 16,56 & 27 & 108 \\
\hline 2 & 3,98 & 107 & 428 \\
\hline 3 & 6,94 & 33 & 132 \\
\hline 4 & 11,72 & 61 & 244 \\
\hline 5 & 12,90 & 39 & 156 \\
\hline 6 & 1,87 & 59 & 236 \\
\hline 7 & 9,61 & 114 & 456 \\
\hline Total & $\mathbf{6 3 , 5 7}$ & $\mathbf{4 4 0}$ & $\mathbf{1 . 7 6 0}$ \\
\hline Kepadatan populasi & $=$ & $\mathbf{2 8}$ jiwa/ha \\
\hline
\end{tabular}

Kepadatan pekerjaan dihitung berdasarkan luasan lantai bangunan dengan standar perhitungan sebagai berikut: fungsi perkantoran $13 \mathrm{~m}^{2} /$ tenaga kerja, fungsi industri $36 \mathrm{~m}^{2} /$ tenaga kerja, fungsi komersial retail $15-20 \mathrm{~m}^{2} /$ tenaga kerja (Homes and Community 2015), hasil perhitungan ditunjukan dalam tabel 5 berikut:

Tabel 5. Kepadatan pekerjaan

\begin{tabular}{lll}
\hline Fungsi & $\begin{array}{l}\text { Floor space } \\
\left(\mathbf{m}^{2}\right)\end{array}$ & $\begin{array}{l}\text { Jumlah } \\
\text { pekerja }\end{array}$ \\
\hline Komersial & 62.044 & 3.102 \\
\hline Perkantoran & 5.342 & 411 \\
\hline Pemerintahan & 9.577 & 737 \\
\hline Gudang & 2.376 & 66 \\
\hline Pendidikan & 7.011 & 467 \\
\hline Transportasi & 23.125 & 1.156 \\
\hline Fasum & 2.119 & 106 \\
\hline Militer & 24 & 2 \\
\hline Total & $111.618\left(\mathrm{~m}^{2}\right)$ & \\
\hline
\end{tabular}

\begin{tabular}{llc}
\hline Fungsi & $\begin{array}{l}\text { Floor space } \\
\left(\mathbf{m}^{2}\right)\end{array}$ & $\begin{array}{l}\text { Jumlah } \\
\text { pekerja }\end{array}$ \\
\hline $\mathbf{1 1 , 1 6}(\mathbf{h a})$ & $\mathbf{6 . 0 4 7}$ \\
\hline Kepadatan pekerjaan $=$ & $\mathbf{5 4 2}$ pekerja/ha \\
\hline
\end{tabular}

Rekap perhitungan

Hasil perhitungan terhadap kondisi eksisting di lokus penelitian terkait karakter pengembangan, ragam pemanfaatan ruang, dan intensitas pemanfaatan ruang diresumekan dalam tabel 6 berikut:

Tabel 6. Resume perhitungan eksisting

\begin{tabular}{lll}
\hline Variabel & Parameter & $\begin{array}{l}\text { Hasil } \\
\text { Perhitungan }\end{array}$ \\
\hline $\begin{array}{l}\text { Karakter } \\
\text { pengembangan }\end{array}$ & Dominasi fungsi & $\begin{array}{l}\text { Komersial } \\
41,4 \%\end{array}$ \\
\hline $\begin{array}{l}\text { Ragam } \\
\text { pemanfaatan } \\
\text { ruang }\end{array}$ & Perumahan & $25,4 \%$ \\
\cline { 2 - 3 } & Non perumahan & $74,6 \%$ \\
\hline $\begin{array}{l}\text { Intensitas } \\
\text { pemanfaatan } \\
\text { ruang }\end{array}$ & $\begin{array}{l}\text { Kepadatan } \\
\text { bangunan }\end{array}$ & $\begin{array}{l}\text { KDB 17,5\% } \\
\text { KLB 0,24 }\end{array}$ \\
\cline { 2 - 3 } & $\begin{array}{l}\text { Kepadatan hunian } \\
\text { pepulatan }\end{array}$ & 7 unit/ha \\
\cline { 2 - 3 } & $\begin{array}{l}\text { Kepadatan } \\
\text { pekerjaan }\end{array}$ & 28 jiwa/ha \\
\hline
\end{tabular}

Selanjutnya resume hasil perhitungan akan dibandingkan dengan standar parameter pelayanan pada tipologi TOD yang ideal akan diterapkan dikawasan stasiun Maguwo, sehingga akan ditemukan kesenjangan antara kondisi eksisting dengan tipologi TOD ideal yang akan dicapai, dan ditemukan rekomendasi untuk mencapai kondisi ideal tersebut.

\section{Tipologi TOD yang ideal untuk dikembangkan}

Untuk menilai tipologi TOD yang ideal diterapkan di kawasan stasiun Maguwo dalam jangka waktu kedepan, digunakan variabel dan parameter yang sama untuk menilai kondisi eksisting kawasan stasiun Maguwo. Perbedaanya adalah pada penilaian eksisting menggunakan data empiris dilapangan, sedangkan pada penilaian tipologi TOD yang akan dikembangkan, data yang digunakan adalah data terkait prediksi karakter, ragam, dan intensitas pengembangan berdasarkan rencana tata ruang wilayah (RTRW), dan rencana detil tata ruang (RDTR) yang akan diimplementasikan.

Data amatan yang digunakan sebagai dasar penilaian ditunjukan dalam tabel 7 berikut: 
Tabel 7. Data amatan terkait rencana tipologi transit-oriented development (TOD) yang akan dicapai

\begin{tabular}{|c|c|c|}
\hline Variabel & Parameter & Data amatan \\
\hline \multirow{2}{*}{$\begin{array}{l}\text { Prediksi karakter } \\
\text { pengembangan }\end{array}$} & Prediksi dominasi fungsi & \multirow{2}{*}{$\begin{array}{l}\text {-RTRW kabupaten Sleman 2011-2031 } \\
\text {-Rencana pengembangan TOD di Daerah Istimewah } \\
\text { Yogyakarta (DIY) berdasarkan RTRW DIY 2019-2031 }\end{array}$} \\
\hline & Prediksi lingkup layanan & \\
\hline \multirow{2}{*}{$\begin{array}{l}\text { Prediksi ragam } \\
\text { pemanfaatan ruang }\end{array}$} & Prediksi persentase fungsi perumahan & \multirow{2}{*}{$\begin{array}{lccr}\text {-RTRW } & \text { kabupaten } & \text { Sleman } & 2011-2031 \\
\text {-Raperda } & \text { RTRW } & \text { Daerah } & \text { Istimewah Yogyakarta } \\
\text { 2019-2039 }\end{array}$} \\
\hline & $\begin{array}{l}\text { Prediksi persentase fungsi } \\
\text { nonperumahan }\end{array}$ & \\
\hline \multirow{4}{*}{$\begin{array}{l}\text { Prediksi intensitas } \\
\text { pemanfaatan ruang }\end{array}$} & Prediksi kepadatan bangunan & \multirow{4}{*}{$\begin{array}{l}\text {-RTRW kabupaten Sleman 2011-2031, } \\
\text {-RDTR kecamatan Depok, Kabupaten Sleman 2012-2032 } \\
\text {-Sistem tata ruang kabupaten Sleman } 2018\end{array}$} \\
\hline & Prediksi kepadatan hunian & \\
\hline & Prediksi kepadatan populasi & \\
\hline & Prediksi kepadatan pekerjaan & \\
\hline
\end{tabular}

Prediksi karakter pengembangan

Disebutkan dalam Recana Tata Ruang Wilayah (RTRW) Kabupaten Sleman tahun 20112031, bahwasannya Kecamatan Depok, Kabupaten Sleman, termasuk didalamnya desa Maguwoharjo sebagai lokasi stasiun Maguwo, kedepan akan berfungsi sebagai Pusat Kegiatan Nasional (PKN) berupa kawasan perkotaan kabupaten, dengan karakter pengembangan dan lingkup layanan sebagai berikut: (a) sebagai pusat akomodasi wisata regional; (b) sebagai pusat pendidikan skala international; (c) sebagai pusat kesehatan skala regional, dan (d) sebagai pusat jasa dan perdagangan regional (Sleman 2011).

Prediksi karakter pengembangan juga dilihat dari rencana pengembangan transit-oriented development (TOD) diwilayah Daerah Istimewah Yogyakarta, dalam rencana tersebut stasiun Maguwo termasuk 1 dari 9 stasiun yang akan dikembangkan menjadi kawasan TOD diwilayah Daerah Istimewah Yogyakarta (Yogyakarta 2019), ini sebagai bagian dari pengembangan dan revitalisasi sistem transportasi darat sebagai penghubung antar pusat kegiatan primer dan sekunder, serta penghubung antara pusat kegiatan dengan wilayah atau kota disekitarnya. Peta sebaran lokasi stasiun yang akan dikembangan menjadi kawasan transit-oriented development (TOD) di Daerah Istimewah Yogyakarta ditunjukan dalam gambar 5 berikut:

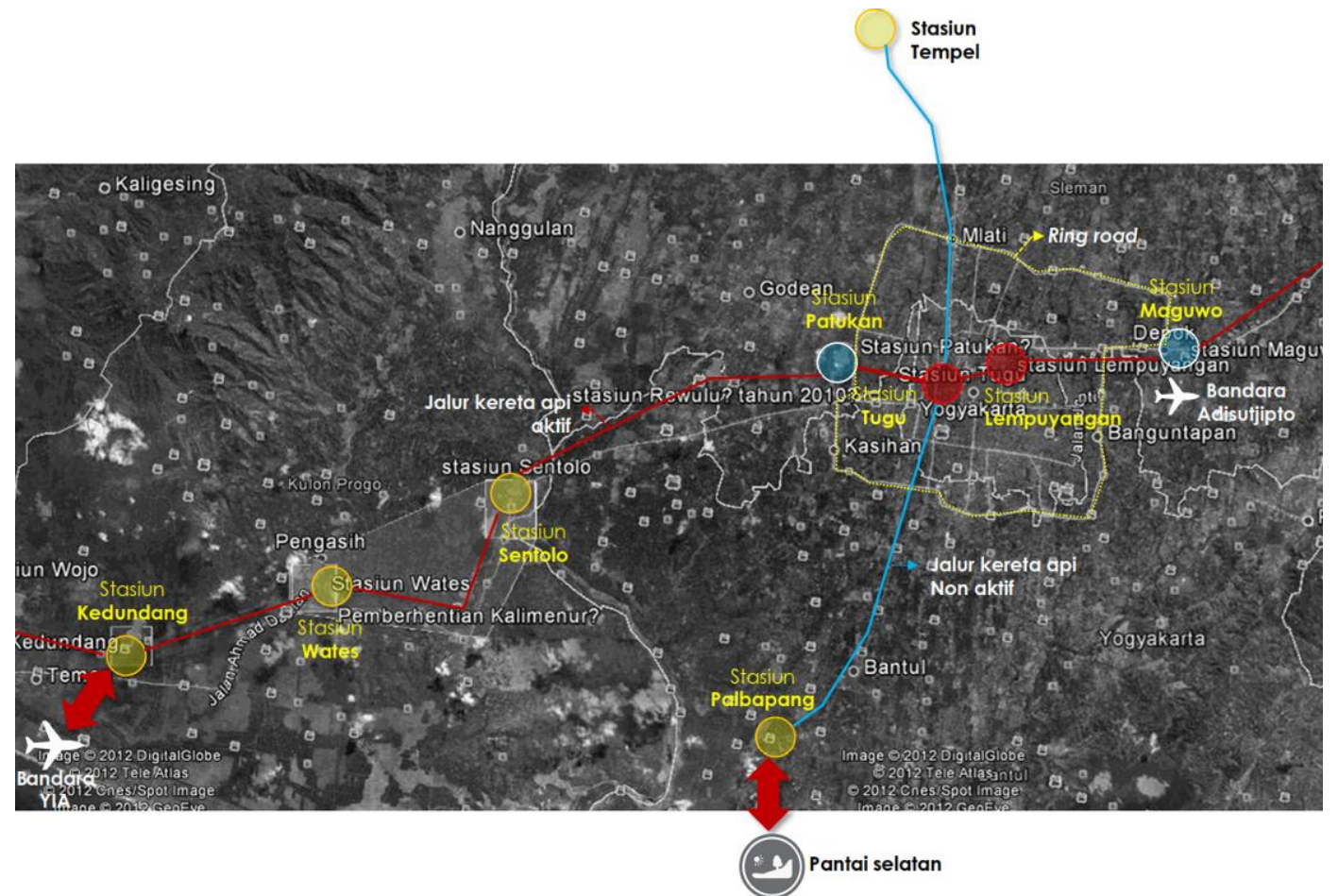

Gambar 5. Lokasi stasiun di Daerah Istimewah Yogyakarta yang akan dikembangkan dengan konsep transitoriented development (TOD) 
Dilihat dari aspek lokasi, keberadaan masingmasing stasiun yang akan dikembangkan memiliki peran dan lingkup layanan yang berbeda-beda. Stasiun Tugu dan stasiun Lempuyangan yang berada dipusat kota Yogyakarta dengan kepadatan tinggi (Putriani and Fauzi 2018), akan memiliki lingkup layanan regional dengan dominasi fungsi nonperumahan. Berbeda dengan stasiun Patukan dan stasiun Maguwo yang berada di antara pusat kota Yogyakarta dan wilayah penyangga serta pedesaan maka, akan memiliki lingkup layanan sekunder dengan kepadatan sedang. Namun, 5 TOD yang lain (stasiun Sentolo, Wates, Kedundang, Palbapang, dan Tempel) akan memiliki lingkup layanan skala lingkungan, kepadatan rendah, dan dominasi fungsi perumahan.

Dari penjelasan karakter pengembangan dilihat dari aspek RTRW dan lokasi stasiun, maka lingkup layanan yang tepat dikembangkan dikawasan stasiun Maguwo adalah lingkup layanan skala sekunder dalam konteks stasiun Maguwo dikaitkan dengan 8 stasiun lain di Yogyakarta yang akan dikembangkan dengan konsep TOD. Dan jika dilihat dari konteks jasa dan perdagangan maka masuk dalam skala pelayanan regional untuk kawasan Yogyakarta dan sekitarnya.

\section{Prediksi ragam pemanfaatan ruang}

Ragam pemanfaatan ruang kawasan stasiun Maguwo seperti yang disebutkan dalam RTRW Kabupaten Sleman tahun 2011-2031 pasal 65 adalah sebagai Pusat Kegiatan Nasional (PKN) dengan ketentuan pengembangan: (a) diperbolehkan fungsi pertokoan modern dengan skala layanan regional; (b) permukiman dengan intensitas sedang - tinggi dan diutamakan hunian vertikal. Pada pasal 52 disebutkan: (a) pengembangan pusat akomodasi wisata regional; (b) pengembangan pusat pendidikan skala international; (c) pengembangan pusat kesehatan skala regional, dan (d) pengembangan pusat jasa dan perdagangan regional.

Dari penjelasan di atas dapat diprediksikan ragam pemanfaatan ruang yang tepat untuk kawasan stasiun Maguwo untuk jangka waktu kedepan adalah dominasi fungsi nonperumahan.

Prediksi intensitas pemanfaatan ruang

Prediksi intensitas pemanfaatan ruang dikawasan stasiun Maguwo diambil dari Rencana Detail Tata Ruang (RDTR) kecamatan Depok, kabupaten Sleman tahun 2012-2032, dan sistem tata ruang kabupaten Sleman tahun 2018, disebutkan dalam peta RDTR kepadatan bangunan nonperumahan yang diijinkan adalah KDB maksimal 60\%, KDH 20\%, KLB 1,8. Untuk pola kepadatan hunian adalah hunian vertikal kepadatan sedang-tinggi, dengan intensitas KDB maksimal 60\%, KDH 20\%, KLB 3,6.

\section{Rekap perhitungan}

Dari analisis data terkait prediksi pengembangan di kawasan stasiun Maguwo pada jangka waktu kedepan, ditemukan karakter pengembangan yang tepat untuk diterapkan di kawasan stasiun Maguwo adalah, kawasan dengan skala layanan sekunder dalam konteks keberadaan stasiun Maguwo dikaitkan dengan rencana pengembangan TOD di 9 stasiun di Yogyakarta, dan layanan skala regional dalam konteks jasa dan perdagangan.

Sedangkan ditinjau dari aspek ragam dan intensitas pemanfaatan ruang adalah dominasi fungsi nonperumahan dengan KDB $60 \%, \mathrm{KDH}$ $20 \%$, KLB 1,8. Sedangkan untuk fungsi perumahan tipologi yang dikembangkan adalah hunian vertikal kepadatan sedang-tinggi dengan KDB 60\%, KDH 20\%, KLB 3,6. Dari temuan di atas kemudian dibandingkan dengan standar tipologi TOD, untuk mendapatkan tipologi TOD yang mendekati hasil amatan terkait prediksi pengembangan tersebut, hasil perbandingan ditunjukan dalam tabel 8 berikut:

Tabel 8. Perbandingan hasil amatan dan standar tipologi layanan transit-oriented development (TOD)

\begin{tabular}{|c|c|c|c|c|c|c|c|}
\hline Variabel & Parameter & $\begin{array}{l}\text { Hasil } \\
\text { amatan }\end{array}$ & \multicolumn{5}{|c|}{ Indikator standar } \\
\hline $\begin{array}{l}\text { Prediksi } \\
\text { karakter } \\
\text { pengembangan }\end{array}$ & $\begin{array}{l}\text { Prediksi lingkup } \\
\text { layanan }\end{array}$ & $\begin{array}{l}\text {-Sekunder } \\
\text { (konteks } \\
\text { pengembangan } \\
\text { TOD di DIY) } \\
\text {-Regional }\end{array}$ & Regional & $\sqrt{ }$ & Sekunder & $\sqrt{ }$ & Lingkungan \\
\hline
\end{tabular}




\begin{tabular}{|c|c|c|c|c|c|c|c|c|}
\hline \multirow{2}{*}{ Variabel } & \multirow{2}{*}{ Parameter } & \multirow{2}{*}{$\begin{array}{l}\text { Hasil } \\
\text { amatan }\end{array}$} & \multicolumn{6}{|c|}{ Indikator standar } \\
\hline & & & \multicolumn{2}{|l|}{ TOD Kota } & \multicolumn{2}{|l|}{ TOD Sub Kota } & \multicolumn{2}{|l|}{$\begin{array}{l}\text { TOD } \\
\text { Lingkungan }\end{array}$} \\
\hline & & $\begin{array}{l}\text { (konteks jasa \& } \\
\text { perdagangan) }\end{array}$ & & & & & & \\
\hline \multirow{2}{*}{$\begin{array}{l}\text { Prediksi ragam } \\
\text { pemanfaatan } \\
\text { ruang }\end{array}$} & Perumahan & \multirow{2}{*}{ Nonperumahan } & $20 \%-60 \%$ & \multirow[t]{2}{*}{$\sqrt{ }$} & $30 \%-60 \%$ & \multirow[t]{2}{*}{$\sqrt{ }$} & $60 \%-80 \%$ & \\
\hline & Nonperumahan & & $40 \%-80 \%$ & & $40 \%-70 \%$ & & $20 \%-40 \%$ & \\
\hline \multirow{2}{*}{$\begin{array}{l}\text { Prediksi } \\
\text { intensitas } \\
\text { pemanfaatan } \\
\text { ruang }\end{array}$} & \multirow{2}{*}{$\begin{array}{l}\text { Prediksi } \\
\text { kepadatan } \\
\text { bangunan }\end{array}$} & $\begin{array}{l}\text {-KDB } 60 \% \\
\text {-KLB non } \\
\text { perumahan 1,8 }\end{array}$ & KDB $80 \%$ & & KDB $70 \%$ & $\sqrt{ }$ & KDB $70 \%$ & $\sqrt{ }$ \\
\hline & & $\begin{array}{l}\text {-KLB } \\
\text { perumahan } 3,6\end{array}$ & KLB $>5$ & & KLB 3-5 & $\sqrt{ }$ & KLB 2-3 & $\sqrt{ }$ \\
\hline
\end{tabular}

Dari perbandingan pada tabel 8 perbandingan hasil amatan dan standar tipologi layanan TOD menunjukan bahwa berdasarkan hasil amatan terkait prediksi karakter, ragam, dan intensitas pengembangan yang akan diwujudkan di kawasan stasiun Maguwo, maka tipologi TOD yang sesuai untuk diterapkan di kawasan tersebut adalah TOD dengan tipologi layanan sub kota.

Beberapa hal yang menjadi kesenjangan atau gap antara kondisi eksisting dengan standar layanan pada tipologi TOD sub kota, serta rekomendasi yang harus dilaksanakan ditunjukan dalam tabel 9 di bawah ini.

Tabel 9. Gap kondisi eksisting dan standar tipologi layanan transit-oriented development (TOD)

\begin{tabular}{|c|c|c|c|c|}
\hline Variabel & Parameter & $\begin{array}{l}\text { Kondisi } \\
\text { eksting }\end{array}$ & $\begin{array}{l}\text { Standar teknis } \\
\text { TOD sub kota }\end{array}$ & $\begin{array}{l}\text { Rekomendasi untuk acuan desain } \\
\text { kawasan }\end{array}$ \\
\hline \multirow[b]{2}{*}{$\begin{array}{l}\text { Karakter } \\
\text { pengembangan }\end{array}$} & Dominasi fungsi & $\begin{array}{l}\text { Komersial } \\
41,4 \%\end{array}$ & $\begin{array}{l}\text { Dominasi } \\
\text { nonperumahan }\end{array}$ & \multirow{2}{*}{$\begin{array}{l}\text { Dominasi fungsi eksisting sudah } \\
\text { sesuai, akan tetapi perlu diperhatikan } \\
\text { standar diversitas untuk pembagian } \\
\text { fungsi non perumahan yang nantinya } \\
\text { akan diterapkan }\end{array}$} \\
\hline & Lingkup layanan & $\begin{array}{l}\text { Sekunder, } \\
\text { regional }\end{array}$ & Sekunder & \\
\hline \multirow{2}{*}{$\begin{array}{l}\text { Ragam } \\
\text { pemanfaatan } \\
\text { ruang }\end{array}$} & Perumahan & $25,4 \%$ & $30 \%-60 \%$ & \multirow{2}{*}{$\begin{array}{l}\text { Desain kawasan perlu ditambahkan } \\
\text { fungsi perumahan untuk mencapai } \\
\text { persentase sesuai standar TOD sub } \\
\text { kota }\end{array}$} \\
\hline & Non perumahan & $74,6 \%$ & $40 \%-70 \%$ & \\
\hline \multirow{4}{*}{$\begin{array}{l}\text { Intensitas } \\
\text { pemanfaatan } \\
\text { ruang }\end{array}$} & $\begin{array}{l}\text { Kepadatan } \\
\text { bangunan }\end{array}$ & $\begin{array}{l}\text { KDB } 17,5 \% \\
\text { KLB } 0,24\end{array}$ & $\begin{array}{l}\text { KDB } 70 \% \\
\text { KLB 3-5 }\end{array}$ & \multirow{4}{*}{$\begin{array}{l}\text { Desain kawasan perlu meningkatkan } \\
\text { densitas bangunan, unit hunian, dan } \\
\text { populasi untuk mencapai persentase } \\
\text { angka kepadatan sesuai standar TOD } \\
\text { sub kota }\end{array}$} \\
\hline & Kepadatan hunian & 7 unit/ha & $\begin{array}{l}\text { Sedang - tinggi } \\
\text { (25 s/d } 38 \text { unit/ha) }\end{array}$ & \\
\hline & Kepadatan populasi & $28 \mathrm{jiwa} / \mathrm{ha}$ & 450-1500 jiwa/ha & \\
\hline & $\begin{array}{l}\text { Kepadatan } \\
\text { pekerjaan }\end{array}$ & 542 pekerja/ha & 40-200 pekerja/ha & \\
\hline
\end{tabular}

\section{Kesimpulan}

Kondisi eksisting kawasan stasiun Maguwo dalam radius walkable distance $(400 \mathrm{~m})$, dilihat dari aspek karakter pengembangan didominasi fungsi komersial dengan skala layanan sekunder dan regional, dengan intensitas kepadatan bangunan rendah, dan kepadatan unit hunian dan populasi rendah.
Prediksi pengembangan kedepan didasarkan pada aspek karakter pengembangan, ragam, dan intensitas pemanfaatan ruang, maka tipologi transit-oriented development (TOD) yang sesuai untuk diterapkan di kawasan stasiun Maguwo adalah tipologi TOD sub kota.

Kesenjangan antara kondisi eksisting dengan kondisi ideal tipologi transit-oriented development (TOD) sub kota, terdapat pada aspek kurangnya jumlah unit hunian dan rendahnya intensitas pemanfaatan ruang. Oleh karena itu 
rekomendasi terhadap desain kawasan nantinya, persentase jumlah dan kepadatan unit hunian harus ditambahkan minimal $30 \%$ dengan kepadatan 25-38 unit/ha, begitu juga kepadatan bangunan (KDB dan KLB), dan jumlah populasi harus ditingkatkan untuk mendekati angka standar kepadatan pada tipologi transit-oriented development (TOD) sub kota.

\section{Referensi}

Brisbane City Council and the Queensland Government. 2011. Residential Form Handbook. Brisbane.

Calthorpe, and Mintier. 2011. "Transit-Oriented Development Design Guidelines," no. September 1990: 87.

Calthorpe, Peter. 1993. The Next American Metropolis: Ecology, Community, and the American Dream. New York: Princeton Architectural Press, Inc.

Community Design + Architecture, Inc. 2001. "Model Transit-Oriented District." California.

Gomez, Christy P, Masitah Omar, and Rameson Nallusamy. 2019. "A Study on the Benefits of Transit Oriented Development in Malaysia And Incoporation of Those Benefits in Planning." MATEC Web of Conferences 266. https://doi.org/10.1051/matecconf/20192660 6016.

Gultom, Kariaman. 2015. 'Pengaruh Heterogenitas Sosial, Ekonomi, Budaya Penghuni Terhadap Heterogenitas Desain Fasad Bangunan Kualitas Kawasan Perumahan, Studi Kasus: Perumnas Klender, Jakarta'. Jurnal Penelitian Dan Karya Ilmiah Arsitektur Usakti 15 (2). https://doi.org/10.25105/agora.v15i2.2025.

Holling, Carlindi, and Fiona M Haslam McKenzie. 2009. "The Attraction and Retention of Small and Medium Enterprises in Transit Oriented Development in Perth," 3940.

Homes and Community, Agency. 2015. Employment Density Guide: 3rd Edition.

Indonesia, Pemerintah. 2017. "Lampiran Peraturan Menteri ATR no.16 Tahun 2017 tentang Pedoman Pengembangan Kawasan Berorientasi Transit." Jakarta.

Kostof, Spiro. 1991. The City Shaped: Urban Patterns and Meanings Throughout History. London: Thames \& Hudson, Ltd.

Landcom. 2011. "Residential Density Guide for Landcom Project Teams." Paramatta.

Motieyan, Hamid, and Mohammad Saadi Mesgari. 2017. "Towards Sustainable Urban Planning Through Transit-Oriented Development ( A Case Study: Tehran )." International Journal of Geo-Information. https://doi.org/10.3390/ijgi6120402.

Putriani, Okkie, and Ibnu Fauzi. 2018. "A Comparative Study of Transit Oriented Development ( TOD ) at Yogyakarta Railway Station." MATEC Web of Conferences 181, https://doi.org/10.1051/matecconf/20181810 2001.

Renne, John Luciano. 2005. "Transit-Oriented Development: Measuring Benefits, Analyzing Trends, and Evaluating Policy," 24.

Sleman, Kabupaten. 2011. "Perda Kabupaten Sleman No.12 Tahun 2012 Tentang RTRW Kabupaten Sleman Tahun 2011-2031.” In . Sleman.

Tong, Xin, Yaowu Wang, Edwin H.W. Chan, and Qingfeng Zhou. 2018. "Correlation between Transit-Oriented Development (TOD), Land Use Catchment Areas, and Local Environmental Transformation." Sustainability (Switzerland) 10 (12). https://doi.org/10.3390/su10124622.

Widyastuti, Dyah Titisari. 2017. "Konsep Pengembangan Kawasan Stasiun Kereta Api: Model Rail-Transit Oriented Development Di Indonesia." Yogyakarta: Universitas Gadjah Mada.

Wijaya, Cecep. 2018. "Padalarang, Antara Kemewahan dan Kawasan Paling Kumuh di Bandung Barat." Pikiran Rakyat media network. 2018.

Wijaya, Alfred, and Sally Octaviana Sari. 2020. 'Analisis Kriteria Desain Jalur Pedestrian Kawasan Stasiun Kereta Api Padalarang'. ARTEKS: Jurnal Teknik Arsitektur 5 (1): 127-34.

https://doi.org/10.30822/arteks.v5i1.363.

Yogyakarta, Gubernur. 2019. "RTRW DI Yogyakarta 2019-2039." In . Yogyakarta. 